\title{
Influence of Non-Genetic Factors on First Lactation 300 Days Milk Yield in Gir Cows
}

\author{
K. B. Savalia ${ }^{1}$, A. R. Ahlawat ${ }^{2 *}$, A. D. Verama ${ }^{2}$, V. V. Gamit ${ }^{3}$, P. G. Dodia ${ }^{1}$, \\ V. B. Dongre ${ }^{4}$ and H. P. Vijeta ${ }^{5}$ \\ ${ }^{1}$ Polytechnic in Animal Husbandry, Junagadh Agricultural University, \\ Junagadh, Gujarat, India \\ ${ }^{2}$ Department of Animal Genetics and Breeding, ${ }^{3}$ Dept. of Livestock Production Management, \\ College of Veterinary Science \& A.H., Junagadh Agricultural University, \\ Junagadh, Gujarat, India \\ ${ }^{4} A G B, I L F C$, College of Veterinary and Animal Science, Udgir, \\ Dist- Latur, Maharashtra, India \\ ${ }^{5}$ Cattle Breeding Farm, Junagadh Agricultural University, Junagadh, Gujarat, India \\ *Corresponding author
}

Keywords

Age at first calving, FL300DMY, Calf birth weight and Gir cow

Article Info

Accepted:

26 September 2020

Available Online:

10 October 2020
The present study was carried out using data of first lactation records of 513 Gir cows sired by 75 bulls spread over a period of 34 years (1981 to 2014), maintained at Cattle Breeding Farm, Junagadh Agricultural University, Junagadh. Analysis was carried out by least squares analysis method described by Harvey (1966) and followed by Duncan's multiple range test. The overall least squares means for first lactation 300 day or less milk yield (FL300DMY) was $1506.36 \pm 40.10 \mathrm{~kg}$. Season of calving had non-significant effect on FL300DMY. Period of calving had highly significant $(\mathrm{P}<0.01)$ effect on FL300DMY. Age at first calving had nonsignificant influence on FL300DMY, while calf birth weight had significant $(\mathrm{P}<0.05)$ effect on FL300DMY.

\section{Introduction}

Livestock play an important role in rural economy and contribute significantly to agricultural GDP of our country. India is believed to be a rich reservoir of livestock biodiversity with 43 registered cattle breeds. The total cattle population of India is 190.9 
million of which 512.5 million is livestock population. Cattle contribute around 37.28 percent of the total livestock population of the country. Total cattle population of Gujarat state is 9.46 million out of which 1.40 million are Gir animals. Gir is well known high yielder milch breed of India and has originated from Gir forests and adjoining districts like Junagadh, Amreli, Bhavnagar, Gir-Somanth, Rajkot, Porbandar and also some parts of Jamnagar, Morbi and Surendranagar districts of Gujarat.

The milk yield is the basic and most important economic trait in dairy animal. The First lactation 300DMY provides most efficient measure to assess the inherent capacity of an individual and indicate the breeding value of a dairy animal accurately. Hence, 300 days lactation milk yield has great importance as a unit measure of profit. Being a trait of quantitative in nature, variation in milk yield is mainly brought about by heredity and environment.

\section{Materials and Methods}

The present investigation was conducted on data comprised of 513 Gir cattle completed first lactation in a span of 34 years from 1981 to 2014 from pedigree cum lactation registers and birth registers of Gir cattle maintained at Cattle Breeding Farm, Junagadh Agricultural University, Junagadh.

The data were classified into 7 periods( first six periods had five consecutive years and last period had four consecutive years). Each year was divided into four seasons viz., summer, rainy, autumn and winter. Data were also classified into five different groups according to the age at first calving and six different group according to calf birth weight.

Analysis was carried out by least squares analysis method to study the effect of various non-genetic factors on AFC described by Harvey (1966) using following model.

Where

$$
Y_{i j k l m}=\mu+a_{i}+b_{j}+c_{k}+d_{l}+e_{i j k l m}
$$

$$
\begin{array}{ll}
Y_{i j k l m}= & \text { Observation on the } \mathrm{m}^{\text {th }} \text { individual in } \mathrm{i}^{\text {th }} \text { season, } \mathrm{j}^{\text {th }} \text { period, } \mathrm{k}^{\text {th }} \\
& \text { age group and } \mathrm{l}^{\text {th }} \text { birth weight of calf } \\
\mu & =\text { Overall population mean } \\
a_{i} & =\text { Effect of } \mathrm{i}^{\text {th }} \text { season }(i=1 \text { to } 4) \\
b_{j} & =\text { Effect of } \mathrm{j}^{\text {th }} \text { period }(j=1 \text { to } 7) \\
c_{k} & =\text { Effect of } \mathrm{k}^{\text {th }} \text { age at first calving group }(k=1 \text { to } 5) \\
d_{l} & =\text { Effect of } \mathrm{l}^{\text {th }} \text { birth weightof calf }(l=1 \text { to } 6) \\
e_{i j k l m} & =\text { Random error, NID }\left(0, \sigma_{\mathrm{e}}^{2}\right)
\end{array}
$$

Duncan'smultiple range test as modified by Kramer (1957) was used for testing differences among different least squares means (using the inverse coefficient matrix) to perform multiple comparison. 


\section{Results and Discussion}

The overall least square mean of FL300DMY or less milk yield in the present study was $1506.36 \square 40.10 \mathrm{~kg}$. Present finding are in agreement to the values reported by Bashir et al., (2002)in Red Sindhi cow and Ramani (2016) in Gir cow.

The values of FL300DMY is considerably lower than those reported by Dangar and Vataliya (2015), Savaliya et al., (2016) and Singh et al., (2016) in Gir cattle and Dongre (2012) in Sahiwal cattle. While present finding is higher than those reported by Khatri et al., (2004) in Red Sindhi cattle, Banik (2004)and Ilatsia et al., (2007) in Sahiwal cattle. The differences in FL300DMY obtained by different workers might be due to differences in breeds, heards, management practices, location, number of observations and climate.

The differences in the estimates of average FL300DMY in Gir cattle reported by many workers might be due to sampling variations, number of observations, herd to herd differences, management practices, differences in breeds and time depending on the period for this particular trait.

\section{Effect of season of calving on first lactation 300 day milk yield}

The effect of different seasons of calving was found to be non- significant on the FL300DMY in Gir cows (Table 1). The least square mean of FL300DMY was observed to be highest in autumn calvers followed by winter, rainy and least in summer season calvers (Figure 1). The summer (1446.65 $\square \square 69.23 \mathrm{~kg})$ and rainy (1479.70 $\square \square 64.47 \mathrm{~kg}$ ) season calvers produced minimum milk yield in the first lactation may be attributed to the higher humidity and the incidence of different diseases. The higher FL300DMY produced by animals which calved in autumn (1557.40 $\square \square 72.48 \mathrm{~kg})$ and winter (1541.70 $\square \square 77.43 \mathrm{~kg}$ ) might be due to more favourable temperature and availability of green fodder in sufficient quantity during these seasons.

Similarly, non-significant effect of seasons of calvingon FL300DMY was reported byUlmekand Patel(1993), Dangar and Vataliya (2015)and Ramani (2016)in Gircattle, Kathiravan et al., (2009), Manoj (2009) andRaja (2010)in Sahiwal cattle, Divya et al., (2014) and Singh et al., (2016) inKaran Fries cattle.

While, significant effect of seasons of calving on FL300 DMY was reported by Singh et al., (2016) in Gir cattle, Kakati et al., (2017)in Frieswal cattle and Petrovic et al., (2015)in Simmental cattle.

\section{Effect of period of calving on first lactation 300 day milk yield}

The effect of period of calving on FL300DMY was found to be highly significant (Table 1). The least squares means for FL300DMY was highest (1874.83 $\square \square 105.91 \mathrm{~kg}$ ) for the animals that calved during 1986-1990may beat tributed to the higher lactation length, followed by P2, P4, P3, P5, P6 and lowest(1286.27 $\square \square 73.29 \mathrm{~kg})$ for the period $>2015$ (Figure 2). The differences in FL300DMY over the periods may be attributed to environmental condition, management practice, fodder availability and differential culling levels on the basis of production. 
Table.1 Least squares means for FL300DMY (kg) in Gir cows

\begin{tabular}{|c|c|c|}
\hline Factors & $\mathbf{N}$ & Mean \pm SE(kg) \\
\hline Overall & 513 & $1506.36 \pm 40.10$ \\
\hline \multicolumn{3}{|c|}{ Season of calving } \\
\hline Summer & 90 & $1446.65 \pm 69.23$ \\
\hline Rainy & 113 & $1479.70 \pm 64.47$ \\
\hline Autumn & 79 & $1557.40 \pm 72.48$ \\
\hline Winter & 231 & $1541.70 \pm 47.43$ \\
\hline \multicolumn{3}{|c|}{ Period of calving } \\
\hline 1986-1990 & 34 & $1874.83 \pm 105.91 * *^{\mathrm{a}}$ \\
\hline 1991-1995 & 96 & $1619.06 \pm 72.28 * * \mathrm{bc}$ \\
\hline 1996-2000 & 62 & $1463.61 \pm 83.14 * *^{\mathrm{c}}$ \\
\hline 2001-2005 & 50 & $1510.64 \pm 91.49 * * b c$ \\
\hline 2006-2010 & 102 & $1420.24 \pm 65.94 * *$ cd \\
\hline 2011-2015 & 96 & $1369.89 \pm 65.57 * * \mathrm{~cd}$ \\
\hline$>2015$ & 73 & $1286.27 \pm 73.29 * *^{\mathrm{d}}$ \\
\hline \multicolumn{3}{|c|}{ Age at first calving(days) } \\
\hline$<1200$ & 37 & $1445.88 \pm 103.30$ \\
\hline 1201-1400 & 120 & $1444.22 \pm 59.39$ \\
\hline 1401-1600 & 161 & $1499.19 \pm 55.21$ \\
\hline $1601-1800$ & 105 & $1576.44 \pm 62.66$ \\
\hline$>1800$ & 90 & $1566.09 \pm 68.10$ \\
\hline \multicolumn{3}{|c|}{ Calf birth weight(kg) } \\
\hline$<18$ & 55 & $1375.03 \pm 53.49 *^{\mathrm{a}}$ \\
\hline $18-20$ & 146 & $1399.07 \pm 82.55^{*^{\mathrm{a}}}$ \\
\hline 20.1-22 & 155 & $1462.33 \pm 51.32 *^{b}$ \\
\hline 22.1-24 & 97 & $1576.08 \pm 63.70 * b c$ \\
\hline 24.1-26 & 38 & $1629.01 \pm 100.11 *^{\mathrm{c}}$ \\
\hline$>26$ & 22 & $1596.66 \pm 131.82 * b c$ \\
\hline
\end{tabular}




\section{Anova table}

\begin{tabular}{|c|c|c|c|c|c|}
\hline Effects & Season & Period & AFC & $\begin{array}{c}\text { Calf birth } \\
\text { weight }\end{array}$ & Error \\
\hline D.F. & 3 & 6 & 4 & 5 & 494 \\
\hline FL300DMY & 268010.81 & $1742510.02 * *$ & 325663.36 & $701298.49 *$ & 341266.84 \\
\hline
\end{tabular}

[** Highly significant at $1 \%$ level $(\mathrm{P}<0.01),{ }^{*}$ significant at $5 \%$ level $(\mathrm{P}<0.05)$, Means with the same superscript are not significantly different, N- No. of Observation]

Figure.1 Season of calving wise least squares means of FL300DMY (kg)

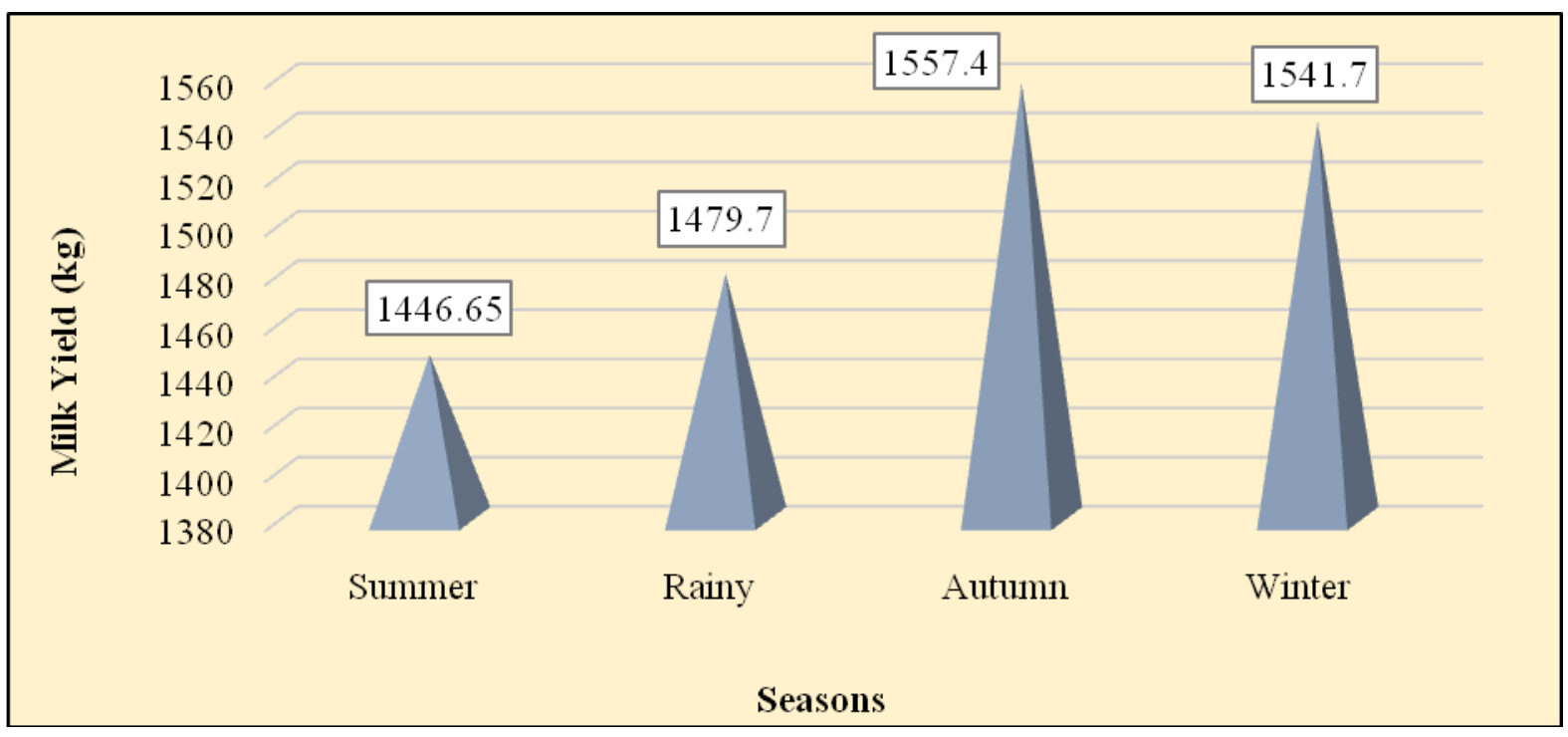

Figure.2 Period of calving wise least squares means of FL300DMY (kg)

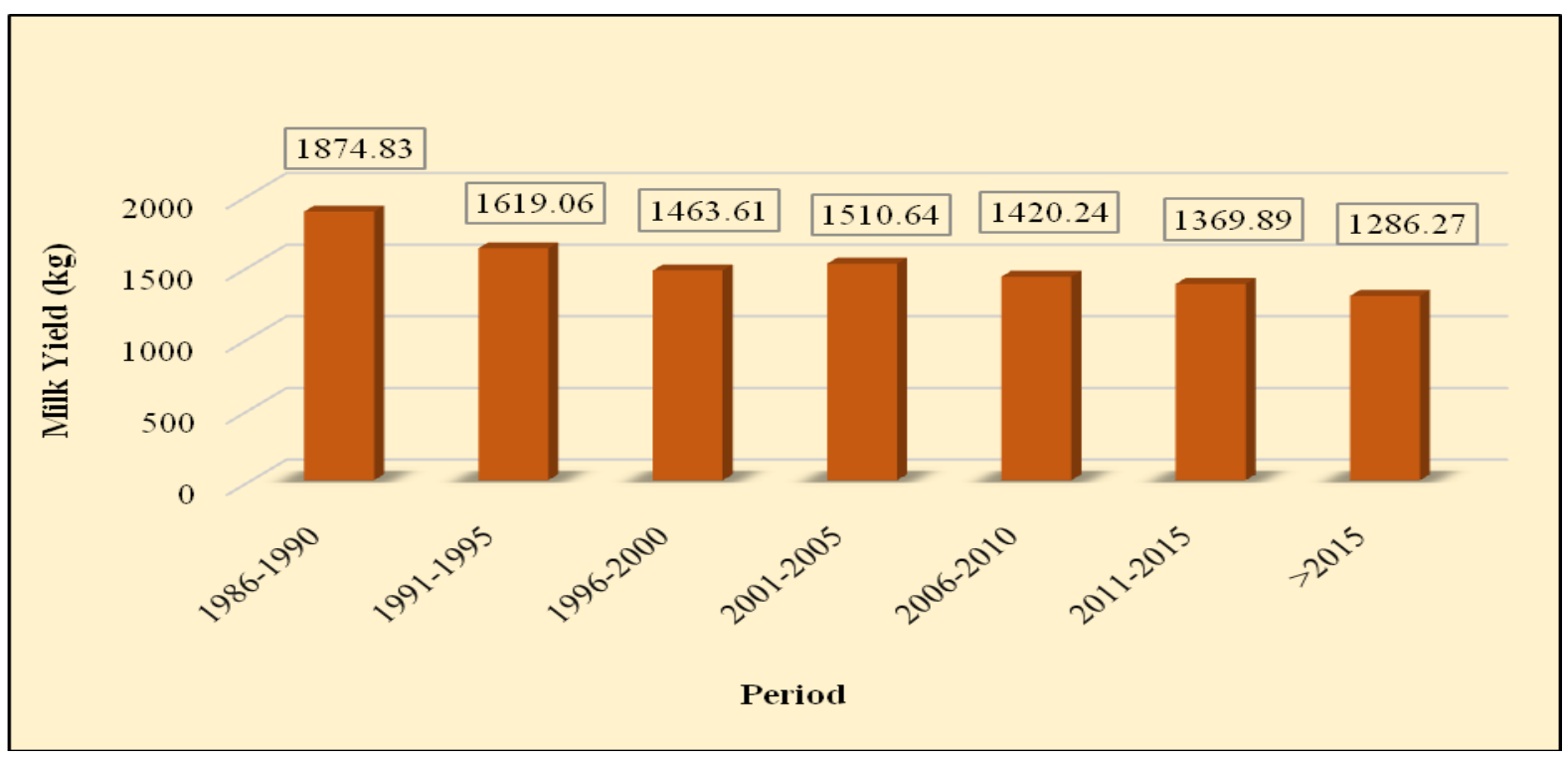


Figure.3 Age at first calving wise least squares means of FL300DMY (kg)

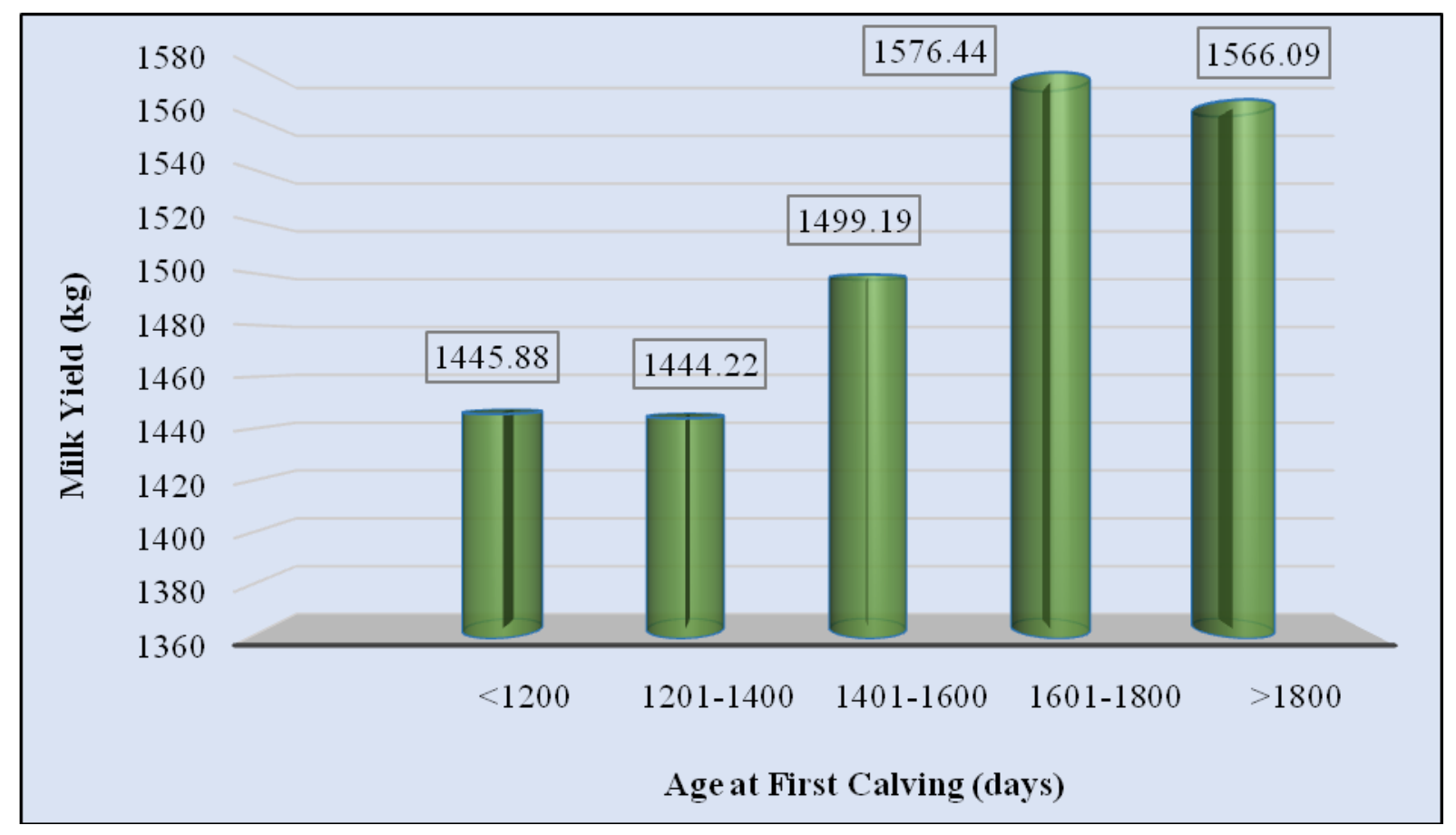

Figure.4 Calf birth weight wise least squares means of FL300DMY (kg)

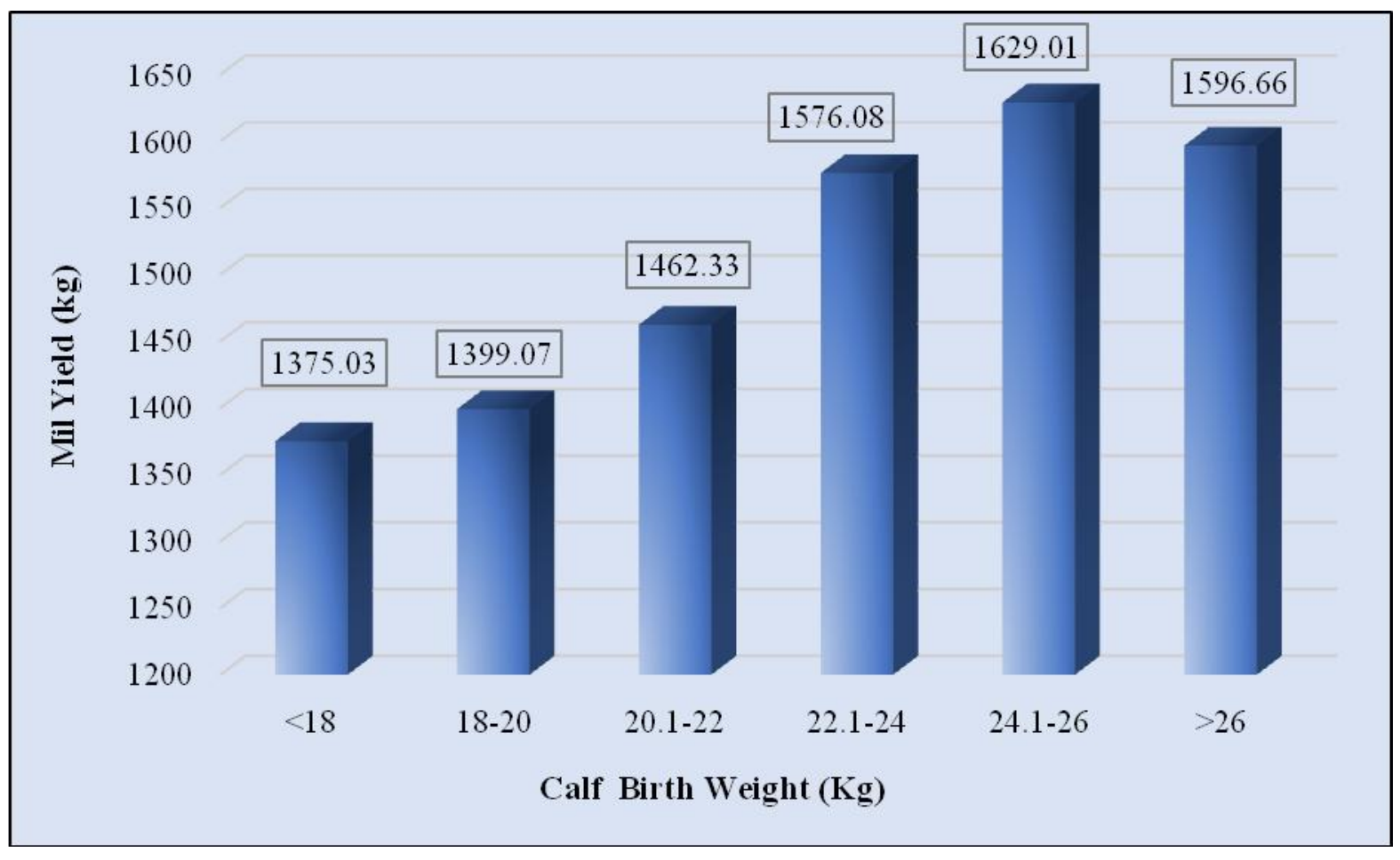


In accordance with the present study, significance effect of period of calving on FL300DMY was reported by Gajbhiye and Dhanda (1987) in Gir cows, Monalisa et al., (2010), Manoj et al., (2012), Dongre et al., (2013) and Narwaria et al., (2015) in Sahiwalcattle and Hussain et al., (2015) in Tharparkar cattle and Rose (2008) in Karan Fries cattle.

Contrary to this, non-significant effect of period of calving on FL305DMY in Sahiwal cattle observed byKushwaha et al., (2003) and Kannan and Gandhi (2004). Similarly, Pandey (2001) in Hariana cattle and Ramani (2016) and Singh et al., (2016) in Gir cows.

\section{Effect of age at first calving on first lactation 300 day milk yield}

The effect of age at first calving on FL300DMY was found to be non-significant in Gir cows (Table 1).

The least square means of FL300DMY was highest (1576.44 $\square \square 62.66 \mathrm{~kg}$ ) in age group A4 than after A5, A3, A1 and lowest (1444.22 $\square \square 59.39 \mathrm{~kg}$ ) in age group A2. In Gir cattle, definite increasing trend was seen in FL300 DMY between A2 to A4 AFC group (Figure 3 ). The reason behind that cows had proper maturing, will have optimum body weight/condition and well developed reproductive system, such cows are likely to perform better for first lactation traits. But non-significant effect of AFC on FL300DMY which may be attributed to better and uniform management of animals maintained during early part of their life.

Non-significant effect of AFC on FL300DMYwas found by Banik and Gandhi (2007), Sentitula (2007), Debbarma (2010), Raja (2010) and Singh et al., (2016) in Sahiwal cattle. Similarly, Take and Murat (2013)in Turkish Holsteins and Divya et al.,
(2014) and Singh et al., (2016) in KaranFries cows.

Contrary to this, Dhaka et al., (2002) in Hariana cows, Rehman et al., (2008), Manoj (2009) and Monalisa et al., (2010) in Sahiwal cattle, Saini et al., (2014) in Rathi cows and Ramani (2016) in Gir cow reported significant effect of AFC on FL300DMY.

\section{Effect of calf birth weight on first lactation 300 day milk yield}

The effect of calf birth weight was found to be significant on the FL300DMY in Gir cows (Table 1). Cows calved with lower calf birth weight between <18 $\operatorname{kg}(1375.03$ $\square \square 53.49 \mathrm{~kg}$ )produced less milk production as compared to cows that calved with higher calf birth weight between 24.1-26 $\mathrm{kg}(1629.01$ $\square \square 100.11 \mathrm{~kg}$ ), the trend of milk production increased within normal calf birth weight (Figure 4). The results indicated that calf birth weight significantly affected $(\mathrm{P} \leq 0.05)$ on the FL300DMY might be due provided better nutritious diet, better health and reproductive management in last trimester of pregnancy in Gir cows.

Similar results were reported by Chew et al., (1981) and Rahbar et al., (2016) in Holsteins cow, Ghoraishy and Rokouei (2013) in Iranian Holstein cattle and Visker et al., (2015) in Holstein Friesian cow.

In conclusions, the first lactation 300 day or less milk yield was not significantly influenced by season of calving and age at first calving. However, it was affected significantly $(\mathrm{P}<0.01)$ by period of calving and calf birth weight in Gir cow.

\section{References}

Banik, S. 2004. Sire evaluation in Sahiwal cattle. Ph.D. Thesis, NDRI, Deemed 
University, Karnal, India.

Banik, S. and Gandhi, R. S. 2007. Association amongst first lactation traits in Sahiwal cattle. Indian J. Dairy Sci.60(3): 181183.

Bashir, M. K., Muhammad, I. M., Yousaf, A. and Bashir, A. 2002. Repeatability estimates of some productive and reproductive traits in Red Sindhi cattle. Pak. Vet. J.22(3): 274-280.

Chew, B. P., Maier, L. C., Hillers, J. K. and Hodgson, A. S. 1981. Relationship between calf birth weight and dam's subsequent 200-and 305-day yields of milk, fat, and total solids in Holsteins. Indian J. Dairy Sci.64(12): 2401-2408.

Dangar, N. S. and. Vataliya, P. H. 2015. Factors affecting lactation milk yield in Gir cattle. Indian Vet. J. 92(7): 71-73.

Debbarma, M. 2010. Genetic analysis of test day milk yield in Sahiwal cattle. M.V.Sc. Thesis, NDRI, Deemed University, Karnal, India.

Dhaka, S. S., Chaudhary, S. R., Pander, B. L., Yadav, A. S. and Singh, S. 2002. Genetic studies on production efficiency traits in Hariana cattle. Asian-Austral. J. Anim. Sci.15(4): 466-469.

Divya, P., Singh, A. and Alex, R. 2014. Standardization of voluntary waiting period and evaluation of production and production traits in Karan Fries cows. Haryana Vet.53(2): 113-116.

Dongre, V. B. 2012. Modeling lactation curve for sire evaluation in Sahiwal cattle. Ph.D. Thesis, NDRI, Deemed University, Karnal, India.

Dongre, V. B., Gandhi, R. S., Singh, A., Vataliya, P. H., Sonawane, G. S., Ahlawat, A. R. and Raja, T. V. 2013. Detection of different shapes of lactation curve for milk yield in Sahiwal cattle by different lactation curve models. Indian J. Vet. Sci. 1(1): 324335.

Gajbhiye, P. U. and Dhanda, O. P. 1987. Sire evaluation and production performance of Gir cattle. Indian Vet. J.64(12): 1043-1048.

Ghoraishy, S. H. and Rokouei, M. 2013. Impact of birth weight of Iranian Holstein calves on their future milk production and reproductive traits. $J$. Livest. Sci. Tech. 1(2): 39-44.

Harvey, W. R. 1966. Least squares analysis of data with unequal sub-class numbers. 20(8). Agricultural Research Services, United State Department of Agriculture.

Hussain, A., Gupta, A. K., Dash, S. K., Manoj, M. and Ahmad, S. 2015. Effect of non-genetic factors on first lactation production and reproduction traits in Tharparkar cattle. Indian J. Anim. Res. 49(4): 438-441.

Ilatsia, E. D., Muasya, T. K., Muhuyi, W. B. and Kahi, A. K. 2007. Genetic and phenotypic parameters and annual trends for milk production and fertility traits of the Sahiwal cattle in semi-arid Kenya. Trop. Anim. Health Prod.39(1): $37-48$

Kakati, P., Panchal, D., Patel, A. C., Bahuguna, P. K., Joshi, R. S. and Rank, D. N. 2017. Genetic parameters of production and reproduction traits and factors affecting it in Frieswal Cattle. Int. J. Livest. Res.7(7): 190-199.

Kannan, D. S. and Gandhi R.S. 2004. Influence of non-genetic factors on life time traits in Sahiwal cattle. Indian J. Dairy Sci.57(3): 185-187.

Kathiravan, P., Sachdeva, G. K., Gandhi, R. S., Raja, T. V., Singh, P. K. and Singh, A. 2009. Genetic evaluation of first lactation production and reproduction traits in Sahiwal cattle. J. Livest. Biodiver. 1(2): 51-55.

Khatri, P., Mirbahar, K. B. and Samo, U. 2004. Productive performance of Red Sindhi cattle. J. Anim. Vet. Adv. 3(6): 353-355.

Kramer, C. Y. 1957. Extension of multiple 
range tests to group correlated means. Biometrics. 13(1): 13-18.

Kushwaha, S., Khan, F. H., Singh, A. and Nanavati, S. 2003. Studies on reproductive efficiency in Sahiwal cattle. Indian Vet. J. 80(3): 247-251.

Manoj, M. 2009. Evolving multi-trait selection criteria using body weights and first lactation traits in Sahiwal cattle. M.V.Sc. Thesis, NDRI, Deemed University, Karnal, India.

Manoj, M., Gandhi, R. S., Raja, T. V., Singh, A. and Sachdeva, G. K. 2012. Effect of non-genetic factors on first lactation production and reproduction performance in Sahiwal cattle. Indian J. Dairy Sci., 65(3): 264-265.

Monalisa, D., Gandhi, R. S., Raja T. V., Avtar Singh and Sachdeva, G. K. 2010. Influence of certain non-genetic factors on test day milk records in Sahiwal cattle. Indian J. Dairy Sci., 63(6): 504506.

Narwaria, U. S., Mehla, R. K., Verma, K. K., Prasad, S., Gupta, A. K., Lathwal, S. S. and Verma, A. K. 2015. Non-genetic factors affecting economic traits in Sahiwal cattle at organized farm. Indian J. Dairy Sci., 68(4): 379-383.

Pandey, S. K., Arora, V. K., Rakesh, G. and Singh R. 2001. Genetic and phenotypic studies of some production traits of Hariana cattle. Indian J. Anim. Res. 35(2): 129-131.

Petrovic, D. M., Bogdanovic, V., Petrovic, M. M., Bogosavljevic-Boskovic, S., Dokovic, R., Dedovic, R. and Rakonjac, S. 2015. Effect of non-genetic factors on standard lactation milk performance traits in simmental cows. Ann. Anim. Sci.15(1): 211-220.

Rahbar, R., Abdullahpour, R. and Sefidmazgi, S. A. 2016. Effect of calf birth weight on milk production of Holstein dairy cattle in desert climate. J. Anim. Behav. Biometeorol.4(3): 65-70.
Raja, T. V. 2010. Part lactation records for Sahiwal sire evaluation. Ph.D. Thesis, NDRI, Deemed University, Karnal, India.

Ramani, A. L. 2016.Inheritance of test day milk yield in Gir cattle. M.V.Sc. Thesis, JAU, Junagadh, Gujarat.

Rehman, Z. U., Khan, S. M., Bhatti, S. A. and Iqbal, J. 2008. Factors affecting first lactation performance of Sahiwal cattle in Pakistan. Arch. Anim. Breed. 51(4): 305-317.

Rose, K. 2008. Studies on lactation curve parameters for milk yield in Karan Fries animals. M.V.Sc. Thesis, NDRI, Deemed University, Karnal, India.

Saini, T., Kachwaha, R. N., Gahlot, G. C. and Sankhala, L. N. 2014. Productivity of Rathi cattle at an oraganised farm under arid zone of Rajasthan. Vet. Pract.15(2): 328-331.

Savaliya, B. D., Parikh, S. S., Gamit, P. M., and Gajbhiye, P. U. 2016. Environmental factors affecting economic traits in Gir cattle. Int. J. Sci. Environ. Sci. Tech., 5(4): 2467-2475

Sentitula, 2007. Ascertaining periodicity in Sahiwal data through time series analysis. M.V.Sc. Thesis, NDRI, Deemed University, Karnal, India.

Singh, A., Singh, M., Gupta, A. K. and Dash, S. K. 2016. Estimation of genetic parameters of first lactation 305-day and monthly test-day milk yields in Karan Fries cattle. Indian J. Anim. Sci., 86(4): 436-440.

Singh, B., Sawant, P., Sawant, D., Todkar, S. and Jain, R. 2016. Factors affecting weight and age at first calving, first lactation milk yield in Gir cows. Indian J. Anim. Res.50(5): 804-807.

Take, B. and Murat, H. 2013. Effect of age at first calving on first lactation milk yield, lifetime milk yield and lifetime in Turkish Holsteins of the Mediterranean region in Turkey. Bulg. J. Agric. 
Sci. 19(5): 1126-1129.

Ulmek, B. R. and Patel, M. M. 1993. Genetic study of milk yield in Gir cattle. $J$. Maharashtra Agric. Univ. 18(3): 435437.

Visker, M. H. P. W., Wang, Y., Van Pelt, M. L. and Bovenhuis, H. 2015. Milk production of the mother is associated with the birth weight rather than the sex of the calf. In Book of Abstracts of the $66^{\text {th }}$ Annual Meeting of the European Federation of Animal Science. pp. 522522.

\section{How to cite this article:}

Savalia, K. B., A. R. Ahlawat, A. D. Verama, V. V. Gamit, P. G. Dodia, V. B. Dongre and Vijeta, H. P. 2020. Influence of Non-Genetic Factors on First Lactation 300 Days Milk Yield in Gir Cows. Int.J.Curr.Microbiol.App.Sci. 9(10): 3739-3748.

doi: https://doi.org/10.20546/ijcmas.2020.910.430 